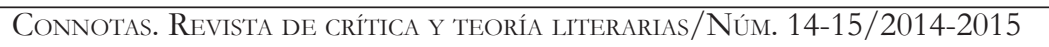

\title{
Dance la luz ocultando su rostro. Resonancias lezamianas de la danza
}

\author{
Alfonso René GutiérReZ*
}

Resumen:

Lezama se sirve de la imagen de la danza como alegoría del nacimiento del acto poético, el cual ve como expresión de la prístina naturaleza de la unidad del alma humana. Participando, de esta forma, de la universalidad que el alma participa al propio acto creador, la danza suele contraponerse en la obra lezamiana a las imágenes de un mundo fragmentado y degradado, mediante una dialéctica en que la crisis que esa negatividad provoca en el arte y la cultura se ve resuelta por virtud de su misma universalidad. Se revisan aquí desde esta perspectiva dos textos poéticos: "Noche insular, jardines invisibles" y Poema.

Palabras clave:

Sensibilidad, insularidad, expresión, americano, tradición, metamorfosis, acto creador, universalidad.

En el ámbito de los estrechos lazos que la labor teórica de José Lezama Lima tiende con su poesía, y de los que esta a su vez establece con aquella, la imagen de la danza suele presentarse como alegoría del nacimiento del acto poético, ostentándose al igual que este, como expresión de la profunda unidad del ser humano. La danza se liga de este modo en la obra de Lezama con algunos temas

\footnotetext{
* Universidad Autónoma de Baja California.
} 
vinculados con el propio acto creador: el desorden y la confusión que usualmente privan en el hombre; la fragmentariedad del mundo moderno y la crisis que esta provoca en la cultura; la dialéctica entre arte popular y arte culto; la interacción de las expresiones culturales trasatlánticas y la sensibilidad cubana, así como el ideal de insularidad que propone Lezama ante esta cuestión: un ideal que es también anhelo de universalidad, entendida no solo como participación en la tradición europea, sino también como incorporación de otras tradiciones mediante un discurso al margen de la causalidad historicista; ${ }^{1}$ esto es lo que confiere su dinamismo característico al método creativo de Lezama, que él enfrenta con la crítica dominada por "un desteñido complejo inferior”, según la definió. ${ }^{2}$ En lo que sigue revisaremos dos momentos de la poesía lezamiana relacionados con la danza, caracterizado el primero por una visión metafísica abierta al extensivo sentido de una crítica moral tanto como cultural, y el segundo por el tránsito de la experiencia del yo a la del mundo, desde la misma conciencia metafísica; los textos correspondientes son, respectivamente, "Noche insular, jardines invisibles" y Poema, este último escrito exprofeso para el ballet.

En Lezama la noción de nacimiento del acto poético puede verse delineada desde temprano, entre otras formas, en los reparos que él opone tanto a la idea de la poesía como absoluta "expresión de un estado de ánimo inefable", como al acrítico predominio de lo subconsciente en el proceso creador. En cuanto a lo primero, Lezama difiere un tanto de lo que en su Coloquio con Juan Ramón Jiménez. (obra que se ha tenido como el inicio de su crítica) y a propósito de Valéry, Juan Ramón sostiene sobre la naturaleza de la poesía; en esta obra elogia el que Valéry haya combatido la poesía como "momen-

\footnotetext{
${ }^{1}$ Para un temprano análisis de este rasgo de la obra lezamiana, Ortega, "La expresión americana"; Ortega lo estudia recientemente en "Lezama Lima".

${ }^{2}$ Complejo "que se derivaría de meras comprobaciones, influencias o prioridades, convirtiendo miserablemente a los epígonos americanos, en meros testimonios de ajenos nacimientos", sostiene Lezama (“Julián” 51), que se había ya referido al cubano como "un pueblo y una sensibilidad que siempre padecieron de complejo de inferioridad" (Coloquio 35.) V. infra, nota 8.
} 
tánea experiencia sensible", persiguiendo, frente al impresionismo y el simbolismo, "un todo coherente volcado sobre la sugerencia", un todo cernido sobre un "tiempo sensible en estado de gracia, virtus inefabile", si bien señala que esto llega a desvirtuarse por "una claridad demasiado rotunda" en el mismo Valéry ${ }^{3}$ (Lezama, Coloquio 38-39) (poco después relacionará esta posición crítica con la poética de $\left.\mathrm{Poe}^{4}\right)$. De este modo, la definición juanramoniana de la poesía como la "suprema adivinación de la vida íntima de los elementos, el agua, el fuego, el aire, la tierra", la reconduce Lezama como vía de equilibrio, hasta la tradicional idea del agua y el fuego cosmogónicos, que como espiritus puros presiden la génesis poética: "en el nacimiento de la poesía como en el origen del mundo", escribe, "hay una lucha entre los elementos plutonistas y neptunistas". Es así que ante el riesgo que para la obra de arte y aun para el mundo de la vida significa la invasión de lo que llamó "el impresionismo del subconsciente", "el pentagrama borroso de la subconsciencia" (que él atribuye a la indicada crisis del mundo contemporáneo), es necesario acogerse al "criticismo dominador" de la expresión que asciende desde la vagarosa corriente de la impresión, señala, rela-

3 Lezama observará poco después, como en un eco de la nietzscheana "calamidad universal" del arte: "Si se elimina la vía iluminativa, el estado poético, como han pretendido Valéry y Jorge Guillén, la poesía queda reducida a una especial combinatoria. Todas las combinatorias han perseguido más la síntesis que la unidad, y así uno de los aspectos más subrayados de la crisis poética actual está en la búsqueda de una síntesis con respecto a escuelas y modos de la sensibilidad, y no de la unidad que nos haga habitable la ingenuidad de un nuevo paraíso" ("Del aprovechamiento" 194-95). Indicó asimismo esta oposición en la "psicología” del personaje novelístico: "Cortázar" 308. O bien Nietzsche 159.

${ }^{4}$ Lezama, "Julián" 50. Al respecto se ha observado que en la primera parte de este ensayo especialmente, Lezama cuestiona "la relación entre las supuestas causas y sus efectos (uno de los grandes temas de Poe quien insiste en su ensayo clásico 'The Philosophy of Composition' [La filosofía de la composición] en invertir precisamente la relación entre la causa y el efecto, convirtiendo el efecto en la causa principal y secreta de su escritura). En lugar de una causalidad racional lineal, Lezama parecería proponer aquí un método de sugerencias, rastros, huellas, concurrencias paralelas o 'roces' metonímicos, contiguos”. 
cionando estos dos elementos con las condiciones de verticalidad estructuradora del fuego y la luz de la llama, y de líquida horizontalidad, respectivamente. ${ }^{5}$

En su ensayo "Doctrinal de la anémona", ante el "continuo método del líquido invasor", yarmada con el "tiempo concentrado" por la contracción del aislamiento poético, la llama se enfrenta a la discontinuidad "inaprovechable" de "lo líquido mal dirigido", situación que domina "convirtiendo un rebelarse en un paso de danza, celebrando obligatoriamente todo nacimiento y muy en especial el poético". Con palabras que recuerdan el designio de regeneración cultural esbozado en la presentación de la revista universitaria Verbum, donde había recriminado a la Universidad "no haber sabido articular su expresión", ${ }^{6}$ afirma Lezama que este nacimiento permitirá sentar los fundamentos de una verdadera expresión insular, ya no de atisbos larvados, como los surgidos hasta entonces en la extensión superficialmente indistinta de la propia sensibilidad isleña, según lo planteaba en el Coloquio..., sino de una expresión que permitirá "la construcción de altos muros", escribe con metáfora martiana, "visibles desde lejos por el tapiz que sirve de base a las torres del imperio" ("Doctrinal" 176). Al igual que otros puntos de este doctrinal, la dionisiaca metafísica del aire que en la llama se infunde, cuya "arquitectura o instrumento es el viento y su destrucción el mismo viento" se muestra tributaria de la visión nietzscheana del mito, y anuncia la propia poética lezamiana de lo incondicionado. ${ }^{8}$

\footnotetext{
${ }^{5}$ Lezama, "Del aprovechamiento" 194; cf. id., "Otra página" 286; id., "Soledades" 137-38, 141; id., "El secreto" 19, 22.

${ }^{6}$ Lezama, "Inicial" 61; id., "Doctrinal" 175-76.

${ }^{7}$ Cf. Martí, 209.

${ }^{8}$ Lezama, "Doctrinal" 176, 177. Cf. vgr., Nietzsche 195-99, o los pasajes en que la danza es la manifestación de la experiencia de "lo misterioso Uno primordial", ibid., 47, 51-52. Con una "voluntad de poderío", escribe Lezama nietzscheanamente, el cubano podría construir el "mito que nos falta" no obstante su "complejo de inferioridad": un mito poético, sustentado por el "sentimiento de lontananza" que nacerá de la espuma de las corrientes marinas, a través de la "resaca" o trasatlántica interacción cultural, con lo que la sensibilidad insular
} 
Contemporáneo del Coloquio... y de "Doctrinal de la anémona", el poema "Noche insular, jardines invisibles" tiene en la imagen de la danza un componente esencial. Subyace en él la idea del fracaso de lo que Lezama definiera como el "afán de integración" del microcosmos del hombre en su moderna circunstancia sociohistórica, parcelación a la que opone la unidad humana primordial que la poesía reactualiza, como ya quedó indicado: si bien el "cosmos integral del español de la época de Carlos V", había observado Lezama, pudo propiciar el "estado de gracia poético" de Garcilaso, al presente, cuando la vida y el fenómeno poético se han "reducido a imagen aislada y soledad agónica" ("El secreto” 11), el acto creador depende de una gracia eficaz, como la que él observa en Juan Ramón ("Gracia eficaz" 260). Presenta este poema un mundo de hombres "furiosos, / como animales de unidad ruinosa", a los que acomete -“más que lebrel, ligero y dividido"- una atmósfera opresiva. Algunos elementos ya presentes en Inicio y escape, el libro del Lezama adolescente (como el del son: "los miembros suyos, anillos y fragmentos,/ ruedan, desobediente son,/ al tiempo enemistado"), resurgen ahora en madurado simbolismo. Hombres en una ciudad de ventanas que "no preguntan, ni endulzan, ni enamoran" y donde "no podrá hinchar a las campanas/ la rica tela de su pesadumbre"; o con ominosa connotación bíblica, tienda que "en la extensión más ciega del imperio,/ con los grotescos signos del destierro,/ como estatua por ríos conducida,/ disolviéndose va, ciega labrándose,/ o ironizando sus préstamos de gloria" (Poesía completa 86-87). Todo lo cual no logra, con todo, acorralar la llama del halcón, imagen con que Lezama había ya alegorizado a Garcilaso (que en la "dimensión neblinosa poética" del "sentimiento nórdico del paisaje", ascendía, "neblí

superará la búsqueda superficial de la poesía que al presente la caracteriza, meramente anecdótica. También estas ideas fueron un tanto influidas por las punzantes páginas de Waldo Frank sobre el pueblo cubano, "La ordalía de Cuba", y sin duda alguna, por el decisivo Seis ensayos en busca de nuestra expresión de Pedro Henríquez Ureña, publicado el año anterior. Cf. Lezama, Coloquio 35-36; Frank 260-78. En su ensayo "Del aprovechamiento poético", Lezama había ya tocado la idea pneumática de la creación. 
neblinoso" hasta un "canon romano insuflado en el ardor castellano"), emparentada también con "la llama, la vibración vertical, hecha de esfuerzo tenso y de extensión particular" que señalara en El Greco ("El secreto" 24); cetrera llama helada en su vuelo sobre el hastio, la ira y el desdén ("ofreciendo a la brisa sus torneos,/ el halcón remueve la ofrenda de su llama,/ su amarillo helado"), atisbando el destierro sombrío e impetrando la posible redención en el único punto en que el discurso adopta la primera persona:

Mudo, cerrado huerto

donde la cifra empieza el desvarío.

Oh cautelosa, diosa mía del mar, tus silenciosas grutas abandona, llueve en todas las grutas tus silencios que la nieve derrite suavemente como la flor por el sueño invadida.

Oh flor rota, escama dolorida, envolturas de crujidos lentísimos, en vuestros mundos de pasión alterada, quedad como la sombra que al cuerpo abandonando se entretiene eternamente entre el río y el eco.

Con ecos de imaginería renacentista, metamorfoseada con los bíblicos colores del pecado se esboza el laberinto de la propia culpa errante:

Verdes insectos portando sus fanales se pierden en la voraz linterna silenciosa. Cenizas, donceles de rencor apagado, sus dolorosos silencios, sus errantes espirales de ceniza y de cieno, pierden suavemente entregados en escamas y en frente acariciada. (Poesía completa 88)

9 "El secreto" 8, 12, 28. 
Como uno más de estos mundos de pasión alterada resurge el tema inicial, introducido por la "esbeltez eterna" del gamo, al son de sus "flautas invisibles" -elemento también presente en los juveniles poemas lezamianos-. Ahora es el diabólico "perro de llamas" en disfraz de "el seductor", que habrá de destrozar al joven ya "trocado en ciervo" (suerte de preludio, este Acteón noctívago, del Foción de Paradiso, en un posible malecón como onírico fondo), "entre rocas nevadas y frente de desazón/ verdinegra, suavemente paseando":

Joven amargo, oh cautelosa

en tus jardines de humedad conocida

trocado en ciervo el joven

que de noche arrancaba las flores

con sus balanzas para el agua nocturna.

Escarcha envolvente su gemido

tú, el seductor, airado can

de liviana llama entretejido, perro de llamas y maldito, entre rocas nevadas y frente de desazón verdinegra, suavemente paseando.

Tocando en lentas gotas dulces la piel deshecha en remolinos humeantes. ${ }^{10}$ (Poesía completa 89 )

Luego de esta sima de disolución se anuncia la promesa (presagiosa del poema "El coche musical", con sus "impulsiones habaneras de la flauta") de la armonía en la noche insular: "la luz vendrá mansa trenzando/ el aire con el agua apenas recordada"11 (Poesía completa 89). Promesa, diremos entre paréntesis, celebrada con los versos que se elegirían como epitafio de Lezama, hímnico festejo

${ }^{10}$ Poco después formulará Lezama esta noción de lo paradisiaco: “éxtasis de participación en lo homogéneo, intemporalidad": "linealidad rota o hinchada por los tres momentos circulares del germen, ente, eternidad, necesarios para apoderarse de su asilo, dejando a la puerta el perro de llamas del Doctor Fausto" ("Extasis" 105).

${ }^{11}$ Cf. Poesía completa 401-06. 
del nacimiento de la poesía: "la mar violeta añora el nacimiento de los dioses, / ya que nacer es aquí una fiesta innombrable". Comienza así a superarse lo que en su comentario a este poema, llamó Cintio Vitier "atmósfera de castigo, de destierro sagrado, de prisión aciaga" (447); cuadros de los que bien se puede suponer que abonan al carácter vivencial reclamado para su obra por Lezama (si bien con la advertencia de que esto no era algo estrictamente biográfico ${ }^{12}$ ); así el citado últimamente, o este otro en que parecería asomar, en un hipotético Castillo del Príncipe (la cárcel en que trabajó Lezama) el joven de uñas pintadas de Paradiso, Martincillo el Flautista:

Las uvas y el caracol de escritura sombría contemplan desfilar prisioneros en sus paseos de límites siniestros, pintados efebos en su lejano ruido, ángeles mustios tras sus flautas, brevemente sonando sus cadenas. (Poesía completa 90)

Se llega, al cabo, entre los meandros de la visión poética, a la promesa que ha de realizarse: la noche se resuelve en cósmica celebración por el futuro nacimiento de los dioses, el nacimiento y triunfo de la danzante luz, restituidora de la perdida unidad:

Una caricia de ese eterno musgo, mansas caderas de ese suave oleaje, el planeta lejano las gobierna con su aliento de plata acompañante. Alzase en el coro la voz reclamada. Trencen las ninfas la muerte y la gracia que diminuto rocío al dios se ofrecen.

Dance la luz ocultando su rostro. Y vuelvan crepúsculos y flautas dividiendo en el aire sus sonrisas. (91-92)

${ }^{12}$ Cf. González, "El ingenuo” 136. 
Meandros de la urbe umbría que se resisten a la luz, tras la rica tela de su pesadumbre:

Inícianse los címbalos y ahuyentan

oscuros animales de frente lloviznada;

a la noche mintiendo inexpresiva

groseros animales sentados en la piedra,

robustos candelabros y cuernos

de culpable metal y son huido.

Mas la justicia impone, al fin, su imperativo:

Dance la luz reconciliando

al hombre con sus dioses desdeñosos.

Ambos sonrientes, diciendo

los vencimientos de la muerte universal

y la calidad tranquila de la luz. (92)

Poema, el otro texto que aquí se comenta, lo escribió Lezama para Forma, un ballet concebido por Alberto Alonso, para el que este encargó la música a José Ardévol; proyecto que (como reafirmando la igualdad en la concurrencia de las distintas artes que Fokine exigiera al ballet) resultó en "un libreto, un poema, una música, una coreografía y una escenografía hechos de común acuerdo -se indicará en el programa de mano- y con intención de lograr la unidad al servicio de la idea inicial", idea que Antonio Quevedo formularía de este modo: "el Hombre viviente y la ordenación de su personalidad ${ }^{13}$ ".

\footnotetext{
${ }^{13}$ Quevedo 51; Pacheco Valera 92. Cf. González y Chinolope 21; Beaumont 147. Alejo Carpentier describía Forma como "una acción situada en lo universal y sin tiempo, que nos muestra al hombre hallando su propia forma -su dimensión interior y la conciencia de esa dimensión- al vivir las fases de toda experiencia humana: contacto con el pueblo, luchas, caídas, hallazgo y fijación del ideal femenino, etc". Sobre esto último Julián Orbón observaba: "La mujer, aparece en sus dos formas más elementales. Ella: imagen de lo eterno, aquella que es para nosotros la fuerza magnífica que mueve nuestro empeño hacia el logro de lo pe-
} 
La propuesta la tomó con entusiasmo Ardévol, quien había expuesto algo semejante en el credo del Grupo de Renovación Musical (que él recién fundara con algunos de sus alumnos del Conservatorio): "Mozart dice que en nuestro arte lo más importante es ordenar el tiempo; y Strawinsky nos explica que la música se le ha dado al hombre con el fin de establecer un orden entre este y el Tiempo ${ }^{14 "}$ (Ardévol, "Grupo" 82). Ya antes de arribar a Cuba admiraba Ardévol a Stravinsky, a quien llegó a conocer en París, admiración subrayada por Alejo Carpentier: el Grupo de Renovación Musical, escribirá este, dedicaba "semanas enteras a la crítica de libros como la Poética musical de Stravinsky". En esta obra el gran compositor volvía sobre el planteamiento antes referido, que Ardévol extraía de sus Memorias; contemporáneamente a estas, Stravinsky había reafirmado en ocasión del estreno de su Perséfone, el ballet con coro y voz narrativa compuesto a partir del poema homónimo de André Gide, que la música "solo nos es dada para poner orden en las cosas: pasar de un estado anárquico e individualista a un estado regulado y perfectamente consciente, garante de vitalidad y duración ${ }^{15}$ ". No es improbable que hasta cierto punto haya inspirado este ballet la resolución de Forma, como quizá sea el caso de lo dispuesto para el coro, que interpretó el texto en el escenario, como ocurría en Perséfone, al margen de la acción: "el problema capital", se explicaría en el programa de mano, "o sea, que

renne, poseído del sentido del 'eterno femenino' goethiano. La Otra: el triunfo de lo fácil y sus seducciones” (Orbón 4; Carpentier, La música 335-36). Auspiciado por la Sociedad Pro-Arte Musical, el ballet se estrenó el 18 de mayo de 1943 en el teatro Auditórium de la misma institución.

${ }^{14}$ Esta era una idea familiar a los músicos cubanos de avanzada. Carpentier indica sobre el que sería gran amigo y colega de Ardévol, Amadeo Roldán: "El pensamiento de Taine: 'la fuerza proviene del orden', podría inscribirse como tema de la producción musical moderna. Y Roldán no ha sido insensible a una general tendencia de su época ... ha sabido construir su obra, con una continua preocupación de oficio" (Carpentier, Crónicas 37).

${ }^{15}$ Stravinsky, "Igor Stravinsky"; Carpentier, La música 332. Cf. Stravinsky, An Autobiography 54; id., Poética, pássim; White 580. 
fueran los mismos que bailaran que los que cantaran, no ha podido ser resuelto más que con la división de labores: unos los que cantan y otros los que bailan; pero no constituyen dos cosas distintas, sino dos aspectos de la misma entidad". El coro "ha sido tratado como narrador a la manera teatral antigua", observará Quevedo, e indicará las "arduas dificultades" vencidas por la Coral de La Habana, bajo la dirección de María Muñoz: "dificultades inherentes a la compleja estructura polifónica, a las entonaciones y figuraciones rítmicas poco habituales, al texto y su pronunciación, al doble acoplamiento instrumental y coreográfico, etc., etc. ${ }^{16}$ ". Considérese que Perséfone, obra a la que llamó Stravinsky en sus Memorias "mi última gran composición" tuvo una proyección especial, debido no en última instancia a la polémica que generó (reflejada en la influyente -en ambos lados del Atlántico como es bien conocido- Nouvelle Revue Française), y que siguió reponiéndose año con año hasta que aquel partió hacia Estados Unidos. En América se representó durante la gira sudamericana a que el propio Stravinsky fue invitado por Victoria Ocampo, quien asistió al estreno mundial de la obra y entabló amistad con él; Stravinsky le obsequió entonces la partitura para piano y aceptó la invitación de buen grado, encomendándole el recitado de Perséfone ${ }^{17}$ (Stravinsky, $A n$ Autobiography 173). Ocampo, que hacía más de una década había debutado exitosamente en la recitación -en el estreno bonaerense de El rey David de Arthur Honegger-, fue la narradora de Perséfone durante la gira, en la primavera de 1936, fecha en que la Editorial

${ }^{16}$ Pacheco Valera 91-92; Quevedo 52. Stravinsky indicó sobre Perséfone: "El coro deberá colocarse al margen de y permanecer fuera de la acción. La separación resultante de texto y movimiento significaría que la escenificación podría ser enteramente trabajada en términos coreográficos... El coro no se movió [en la premier], no de acuerdo con algún precepto estético, sino porque la unión de su trabajo [their labour union] no se lo permitiría." (Stravinsky, Memories 178.) Sobre las dificultades de la parte narrativa durante la representación de Perséfone cf. Stravinsky, In Pictures 330 y White 385.

${ }^{17}$ La mencionada partitura se preserva en la Biblioteca Morgan de Nueva York. Stravinsky, In Pictures 319; Walsh 532-37. 
Sur publicó el propio poema de Gide en traducción de Borges; tres años después reaparecería con gran éxito en el mismo rol, esta vez en Florencia y bajo la dirección nuevamente de Stravinsky. ${ }^{18}$

Por otra parte, en la polémica en torno a Perséfone se ventilaron asuntos de gran vigencia en Cuba. Junto a la crítica adversa de la Nouvelle Revue Française, en las páginas de la misma revista se reconoció al "Stravinsky del estilo internacional" que en esa misma obra, considerada por Charles-Albert Cingria como "el gran evento de la época", dejaba atrás definitivamente el pintoresquismo y el folclor: quienes declaran lo contrario sostuvo Cingria, "se reafirman como más sensibles a lo pintoresco o a ciertas curiosidades folclóricas, o bien a una música adaptada a algún texto predilecto más que al arte puro de la música". Estas cuestiones, reformulación de la antigua querella entre clásicos y románticos, no estaban menos presentes en el momento cubano en el que Forma se realiza, precedido de una apasionada discusión sobre lo nacional y lo universal artístico, de la que Carpentier ofrecerá una concisa recapitulación. ${ }^{19}$

Forma surgía del designio de ser "un ballet que, sin apartarse fundamentalmente de la estructura rítmica de la danza, tuviera un concepto humano universal", comenta Quevedo, quien se congratula de que su rigurosa concepción musical haya sido disfrutada por el público: "el maestro Ardévol compuso una música modal, contenida en puras formas tradicionales: fuga, 'ricercar', 'concerto grosso', 'passacaglia', etc, sin la menor relación formal o expresiva con temas literarios, filosóficos o descriptivos de algún orden". Carpentier la catalogará como una de las obras más importantes ("tanto por la concepción como por la realización") escritas desde principios de siglo en Cuba, e indicará el empleo que hacía Ar-

\footnotetext{
${ }^{18}$ Las representaciones de 1936 tuvieron lugar en el Teatro Colón de Buenos Aires y en el Teatro Municipal de Rio de Janeiro, el 17 de mayo y el 5 de junio, respectivamente (Stravinsky, In Pictures 330; Vázquez 102-03; Ayerza de Castillo y Felgine 180).

${ }^{19}$ Cf. Carpentier, La música 326-29; Cingria, "Perséphone", citado por Walsh 536. Cingria había redactado junto con Stravinsky el artículo citado más arriba, nota 15 .
} 
dévol de melodías del folclor español "como elementos estrictamente musicales en sí, sin buscar en ellos un trampolín poético o una justificación para crear determinado clima orquestal", mientras que Julián Orbón había observado, ya en los ensayos del ballet: "se percibe el intenso aroma de lo mediterráneo, pero un aroma convertido en geometría", puesto que “"Forma' es un ejemplo rotundo de rigor constructivo ${ }^{20}$ ". Ardévol no desdecía, así, la estética que Carpentier, ardiente defensor que había sido del nacionalismo en años anteriores, expresará ahora de esta forma:

Claro está que el nacionalismo nunca ha sido una solución definitiva. La producción musical culta de un país no puede desarrollarse, exclusivamente, en función de un folklore. Es un mero tránsito. Pero un tránsito lo bastante inevitable para haberse hecho necesario a todas las escuelas musicales de Europa. Gracias al canto popular -bien lo señaló cierta vez Boris Scholoezer- las escuelas del Viejo Continente adquirieron su acento propio... Hallado el acento nacional con ayuda del documento viviente -no de otro modo procedió Glinka-, el músico del Nuevo Mundo acaba por liberarse del folklore,

\footnotetext{
${ }^{20}$ Quevedo 52; Carpentier ibid., 333, 335; Orbón 4. "La etapa actual de Ardévol", observará Carpentier, "se caracteriza por una mayor importancia concedida a los valores líricos”, luego de la etapa iniciada a mediados de la década anterior, “caracterizada por una excesiva austeridad". En referencia a esta última, Hilario González comenta que para Ardévol, "resultaba fundamental que no se pudiera sospechar el menor romanticismo en lo que producía -cuestión de principios de aquella vanguardia nutrida en el Manifiesto Futurista de Marinetti- y estrenó una serie de Sonatas a III [...] que fueron famosas por su aridez", y relata al respecto: "En uno de los conciertos, al salir, nos dice Lezama: ‘Este Ardévol compone una música espartana...: de esparto!”; mas la de Forma, agrega González, fue "una música nada espartosa y nada Marinettica. Por el contrario, es una partitura notablemente grata”. Lezama observó sobre el escándalo ocurrido en el estreno (1948) de la Suite cubana de Ardévol: "Claro que la protesta era injusta y la obra de Ardévol, trabajada sobre temas populares nuestros, está muy distante de sus antiguos ejercicios abstractos" (Carpentier ibid., 334, 335;González y Chinolope ibid.; Rodríguez Feo 87).
} 
por proceso de purificación y de introspección, hallando en su propia sensibilidad las razones de una idiosincrasia. ${ }^{21}$

Estética que el propio Ardévol había reivindicado en un artículo que fue un ajuste de cuentas con el regionalismo, a propósito del estado de la música en Cuba, publicado en el primer número de Espuela de Plata: "Agua clara en el caracol del oído" -título de probable influjo lezamiano; una reivindicación ciertamente de acuerdo con las razones de una idiosincrasia que Carpentier señalaba, por las que había ya elegido Ardévol, como elemento popular para ser elaborado en Forma aquel de origen español, connatural a él. No otro es el que está implícito en su crítica del regionalismo:

El acercamiento al arte popular ha sido uno de los fenómenos de más decisiva importancia en la higienización de la música -enferma de wagnerismo sinfónico germano y melodrama italiano-. Ahora bien, creo que en la actualidad la música con elementos populares solamente tiene razón de ser si se proyecta en la dirección que Falla impuso a su arte ... [que] se ha ido alejando cada vez más de todo lo particularista, lo exótico, lo localista (Ardévol, "Agua clara" 60) 22.

Coincidía esta postura con la de Lezama, que en el Coloquio con Juan Ramón Jiménez había alabado el "precioso sentido de lo universal" del hombre andaluz, ya manifiesto, indicaba, desde la época de Alfonso el Sabio, "cuando la cultura oriental resolvió una síntesis con la tradición cristiana grecolatina, gracias a lo cual el andaluz se incorporó al europeo"; sostenía Lezama que "la expresión mestiza es, por el contrario, disociativa, y nos obliga a retrotraernos a la solución de la sangre, al feudalismo de la sensibilidad", afirmando que "la expresión de los andaluces no tiene que ver nada con el an-

${ }^{21}$ Carpentier ibid., 328-29.

${ }^{22}$ Como interés de la música nueva, señalará Ardévol "la pureza de su concepción, y la limpieza del agua clara" ("Grupo" 82). 
dalucismo". Ante la opinión de Juan Ramón sobre una disímbola naturaleza de las sensibilidades insular y continental (el mito de la insularidad, le comentó este a Lezama, suscitaría acaso "un orgullo disociativo, que quizás los apartase a ustedes prematuramente de una solución universalista"), y ante su argumento de que, para esta última, la poesía era "una eficaz resolución de los momentos del espíritu”, Lezama había observado desde su dialéctica de opuestos, que no rehuia, la primera, las "soluciones universalistas" 23 ".

En cuanto al arte afrocubano, aunque Ardévol reconocía en este el "poderoso exorcismo" que había obrado en la sensibilidad cubana actual (la que "le debe, en gran parte, el alejamiento de la preferencia por el arte decadente y sensiblero"), Ardévol censuraba la acrítica aceptación y el influjo desmedido de sus raíces populares: "hoy lo más sano sería dejar a un lado todo lo típico", escribía, "todo exagerado localismo y exotismo. Así se ha apartado Falla de todo limitado andalucismo y Bela-Bartok del cingarismo" (Ardévol, "Agua clara" 60). De hecho, siguiendo el ejemplo de sus dos amigos y hermanos mayores musicales, Amadeo Roldán y Alejandro García Caturla, Ardévol había compuesto en la década anterior piezas para conjunto de percusiones muy influenciadas por elementos afrocubanos, que fueron algunas de las muestras más tempranas de ese género de reciente desarrollo, y las que no solo despertaron el interés sino llegaron a influir en la obra de músicos extranjeros como Henry Cowell, Lou Harrison y John Cage; a petición de este último, Ardévol había escrito recientemente un Preludio a 11, también para grupo de percusiones, que Cage estrenó en Nueva York el mismo año de Forma. El haber permanecido inédita determinó que esta labor pionera de Ardévol se mantuviera prácticamente desconocida, aunque en Estados Unidos dirigió Cage estas piezas en varias ocasiones. Unos años después estrenaría Ardevol una Suite cubana, no digerida por la totalidad el público; Lezama comenta que "hubo algo de la noche de Hernani" en el teatro: "Gritos, pateaduras y muecas y vivas. Pequeño escándalo que viene

${ }^{23}$ Lezama Lima, Coloquio 41, 42. 
a poner un poco de equivocada pimienta en nuestro mundillo ${ }^{24}$ ” (Rodríguez Feo 87).

Tal era la idea universal que Ardévol se hacía de su arte ("no creemos más que en la música única y eterna"), reafirmada en el citado credo del Grupo de Renovación Musical, que emparentaba en algunos de sus puntos con "Razón que sea" - esa especie de manifiesto que Lezama publica en el número inaugural de Espuela de Plata, de la que el propio Ardévol fue consejero desde esos inicios-, tales como "el odio" a "la selva, a lo exótico, a los ríos que se desbordan" o "el amor a la construcción, al dibujo, a lo angélico $^{25}$ ”. Orbón se hacía eco de este credo en su ponderación de tal universalismo, cuando describía Forma como "la soberbia lucha del mundo angélico (El Hombre) contra el mundo de las tinieblas (Su Otro Yo), el juego de la forma y la disolución, de la 'anécdota' y la

\footnotetext{
${ }^{24}$ Carpentier había empleado el mismo símil a propósito de la Obertura sobre temas cubanos de Roldán: "provocó en nuestro ambiente una suerte de pequeña batalla de Hernani”. Estudio en forma de preludio y fuga (1933) y Suite para instrumentos de percusión (1934) son las otras piezas indicadas de Ardévol. Su estreno estadounidense, bajo la dirección de Cage, tuvo lugar en Mills College en 1940 (durante la guerra no pudieron ejecutarse debido a que incluían sirenas, que se habían prohibido); el estreno del Preludio a 11 se dio en el concierto de la Liga de Compositores de 1943 (que situó a Cage a la cabeza de la música experimental). Una muestra de la restringida difusión de estas obras es que el mismo Carpentier, que pasó esos años en el extranjero, comentó en La música en Cuba: "Ardévol habrá de integrarse, algún día, en la tradición musical cubana, al tratar un material sonoro, nuevo para él, con el espíritu que le ha llevado ya a especular con expresiones populares españolas". En este sentido, Harold Gramatges escribió por esos mismos días: "Un músico como Ardévol, siempre fiel, en el momento de realizar, a lo más hondo de la concepción de cada obra, no podía anticipar caprichosamente, por acto de inteligencia (lo digo pensando en su gran dominio y en su fuerza imaginativa al construir), la cubanización de su música. Sólo un proceso natural de integración, tanto en el orden artístico como en el humano, le podía conducir a expresarse en el grado de concreción cubana con que lo hace en el presente" (Carpentier, ibid, 336; id., Crónicas, 92; Díaz 61, 72-73; Hall 46; Gramatges, "Nueve piezas").

${ }^{25}$ Ardévol, “Grupo" 82, 83. Cf. Lezama Lima, “Razón” 51.
} 
"categoría"'26 (4), de modo análogo a la oposición que Lezama había señalado de la "sustancia mítica" o "esencia vivencial" y el "accidente coloreado", en el Coloquio con Juan Ramón Jiménez:

El riesgo de que Forma fracasara en la comunicación de este sentido metafísico fue "un peligro mayor que el de Icaro", comentaba Quevedo en alusión al "ballet de tipo experimental" que Alexandra Denisova, la mujer de Alberto Alonso -ex integrante, como él, de los Ballets Rusos del Coronel de Basil, que aquí representaba "el eterno femenino de 'Ella"'- había montado esa misma temporada de Pro-Arte, con la coreografía de Lifar y música de Harold Gramatges. Ayudó a sortear esta dificultad la coreografía de Alonso, "que recientemente", comenta Orbón, "nos ha ofrecido en 'Petroushka' una prueba de su gran talento". Una coreografía calificada de "obra maestra" por el mismo Quevedo, de expresividad que debió acentuarse con la sensualidad de ciertos pasajes: "son las pasiones", escribe este, "tan necesarias al hombre que sin ellas nuestra existencia estaría regida por leyes geométricas. Un hombre sin pasiones - dice Ichaso- es como un planeta sin atmósfera ${ }^{27 ” . ~ O r b o ́ n ~ e l o g i a ~ n o ~ s o l o ~}$ la plasticidad de la transcripción coreográfica (el "poderoso sentido de lo poético popular" por el que "siempre nos parece hallarnos en medio de una multitud que bulle en poesía") sino también la del poema de Lezama, igualmente idónea a la percepción del sentido de la obra: "Por ejemplo, en la magnífica sensación de pureza, de intensidad apacible que nos producen las frases que canta el coro en el prólogo, mientras la imagen del Pensador permanece recortada en el fondo del escenario: 'Mi dolor no es el arco de la Luna/ Que mi espalda refleja ni la estrella desnuda/ Que levanta una fría estrella contemplativa'. Este poderoso sentido de lo poético popular de que hablamos, lo podemos encontrar también en la deliciosa y

${ }^{26}$ Orbón ibid. "La circunstancia o anécdota", escribía Ardévol, "de por sí no es nada; lo importante es lo que hacemos con tal o cual dosis de polvo que se lleva el tiempo. [...] Todo consiste en convertir la circunstancia en Categoría, en fijar la anécdota en el cielo de la eternidad" (Ibid., 79, 80). V. infra, nota 32.

${ }^{27}$ Quevedo 52, 53-54; Orbón ibid.; cf. Pacheco Valera 90. 
profunda melodía antigua, que expresa la alegría de las gentes en la primera escena". Y agrega: "Apenas sí se puede contener el entusiasmo cuando el coro dice serenamente: 'Mi dolor, mi alegría que yerra por espejos errabundos'. Tal es la enorme fuerza, el contenido de sugerente plasticismo del poema de Lezama". ${ }^{28}$

Cumplían así, música, palabra y coreografía la función que Mallarmé definió como alegórica o emblemática del ballet, donde los pasos de la bailarina, afirmó, son una metáfora de la que el espectador -en la medida en que su instinto poético se los revela- reconoce los conceptos: "escribiendo silenciosamente la propia visión en la forma de un Signo, el significado que ella misma es ${ }^{29}$ ". Lezama elogiará desde esta perspectiva, tiempo después, la capacidad de Alicia Alonso de esclarecer el misterio que media entre la idea y la expresión, que ella "desenvuelve como gráciles asociaciones de conceptos e imágenes en el río del tiempo", así como la forma en que trasmite "la seguridad de que una idea o una sensación pueden ser danzadas"; la seguridad de que la sensación y la idea "tienen su reverso para su reaparición":

de que el instante tiene dos ademanes, uno que se extingue y se evapora, y otro que desea ser danzado, desvaneciéndose también en la seguridad de su ritmo repetible. Sonido o ademán que vuelven a su mañana de renacer en la deliciosa trampa del ritmo... Representación del reverso de las cosas, cuando esas figuras o representaciones se vuelven a su germen, después de ser danzadas, comprobando en los puntos de su marcha la seguridad de su diseño (Lezama, "Sucesiva" 241-42.).

Los movimientos de la danza pueden, de esta forma, despertar ideas tan eminentemente metafísicas como las relativas a lo que el mismo Lezama (en relación con lo que "fue sin duda el más po-

${ }^{28}$ Orbón ibid.

${ }^{29}$ Mallarmé 158, 173, 175, 178. 
deroso imán de toda su creación poética", según se ha observado) llamó el "eterno reverso enigmático": ideas que revestían imágenes -señaló Ramón Xirau, 84- empleadas para "referirse y referirnos a lo que de verdad le importa a Lezama Lima: para referirse a Dios":

Mi dolor no es el arco de la Luna

Que mi espalda refleja ni la estrella desnuda

Que levanta una fría estrella contemplativa.

Mi dolor, mi alegría, que yerra por espacios errabundos, la sustancia alcanzada de la roca erigida, no son mi centro oscuro que detengo y te ofrezco. ${ }^{30}$

Forma aspiró de este modo, al carácter ritual que el ballet adquiere cuando en él es "enunciada la Idea", según sostuvo Mallarmé, que consideró tal evento como poesía por excelencia dentro del género teatral: "toda la Danza no es más que la sagrada y misteriosa interpretación de ese acto ${ }^{31}$ ". Por demás está decir que el sentido trascendente por el que el acto poético se analoga con la creación divina y se consagra, por lo tanto, como redención estética es el sentido mismo de Poema, en puntual consonancia con "la idea básica" de Forma, que en Alberto Alonso había surgido de la contemplación de la Puerta del Infierno de Rodin (Pacheco Valera 91). Así pudo hablar Orbón como se ha visto, de la lucha del mundo angélico contra el de mundo de las tinieblas, en estricta coincidencia con el credo proclamado por Ardévol:

Este es, en realidad, el mito más grande que posee el hombre: de un instante pasajero, de un grano de arena que nos proporciona el azar, o, tal vez, de una circunstancia afanosamente buscada, hacer algo perdurable, más allá del tiempo; de composición arbitraria, de estirpe esencialmente humana, puesto que esta cosa es hija del hombre, sin que en el maridaje haya

\footnotetext{
${ }^{30}$ Id., Poesía completa 667; Xirau 84. Cf. Lezama Lima, Paradiso 502; id., Orbita 30.

${ }^{31}$ Mallarmé 158, 175.
} 
intervenido directamente la naturaleza. Realizado el milagro - milagro de todos los días y todos los siglos- nada pueden ya el tiempo ni su secuela de muerte y anécdotas ${ }^{32}(80)$.

Así Poema recrea la dialéctica de la anécdota y la categoría: "Pero te veo de pronto salvadora enemiga,/ a mí llega la nube y el ruido de la abeja,/ y clara enemiga te sorbo y me creas". Triunfa la soberanía del son, símbolo que lejos del degradado, desobediente son de "Noche insular..." ostenta ahora su natural positividad. Un rumor, luego, alcanzado en soberania exquisital del arco y de la flecha, de signo ya contrario al del "airado redoble en flecha y muerte" de Muerte de Narciso, indicio tal vez del sentido en que afirmó Lezama que representaba, este último poema, "una despedida de la adolescencia" ("tiene en germen como toda la posibilidad del desarrollo futuro de mi obra"); sentido que sería de este modo, el del misterio de una revelación, desde el momento en que el misterio en las astas del ciervo, sugiere que la soberanía del arco y de la flecha apunta al sentido paulino del cazador cazado; al misterio que con plenilunio suelta sus monstruosas escamas, imagen que recuerda la implícita relación de la escamada sierpe antigua y los ojos de Saulo transformados, en el poema de Julián del Casal. ${ }^{33}$ Signado de esta forma, el hombre se mantiene a salvo de la amenaza terrible de la muerte, la que en Poema "no grita en el tambor de las cabalgatas", verso que sin duda se refiere al estruendo de la gran cabalgata fúnebre del Apocalipsis (9, 9), dada la mención que al final se hace del "ángel de la llave entregada" (cf. Apoc. 9, 1). Lezama se referirá por estos días a "la potestad del escorpión (Apocalipsis 9-5), que no ataca el verde, sino al hombre que no tiene signo en la frente. La potestad del escorpión en alianza con el splendor formae. La sustancia natural no se muda. El alma racional recibe la luz inteligible por medio de la figura iluminada o plenitud." En "Las imágenes posibles", el primer texto en que expone

32 Ardévol 80.

${ }^{33}$ Cf. Lezama Lima, Poesía completa 667, 668. Cf. id., Antología 411; Martínez Laínez 66. 
totalizadoramente como se ha observado, lo que había de llamar su sistema poético, definirá Lezama la noción de splendor formae como la culminación de las metamorfosis del ser, plenitud que en Poema se erige como suprema ordenación de la humana imagen y semejanza, como el orden que concede la luz inteligible de la figura iluminada:

La creación se extiende en definida alegría, el zumo de los labios ya no desea y crece el rumor alcanzado en soberanía exquisita del arco y de la flecha, de la flecha y el son.

De la nevada testa el viento remoza los cabellos y cierzo de la muerte revierten los diamantes de la postrer mirada que se lleva el gran río. El coro de guerreros afina sus pisadas. y la muerte no grita en el tambor de las cabalgatas. Definido está el aire: el secreto del ave ya no está mantenido y la redención del pez comprende la secreta soledad del hombre que ayer preguntaba errabundo.

Ahora el misterio en las astas del ciervo Con plenilunio suelta sus monstruosas escamas. ${ }^{34}$

Como se ha visto, la imagen de la danza se vincula íntimamente en la obra de Lezama con su idea del acto creador, acto que al igual que lo hacen las culturas tradicionales él sitúa en una dimensión sagrada. En otros textos lezamianos esta imagen es también alegoría del naciente acto poético, constituyéndose en ellos, al articular la crítica de la pasiva imitación de Europa y de la falsa creación, en eficaz elemento organizador.

\footnotetext{
${ }^{34}$ Lezama Lima, "Extasis" 105; cf. id., "Las imágenes" 135; id., Poesía completa
} 189-90. 


\section{Obras consultadas}

Ardévol, José. "Agua clara en el caracol del oído". Espuela de plata. Cuaderno bimestral de arte y poesía. La Habana 1939-1941. Ed. y pról. de Gema Areta. Sevilla: Renacimiento, 2002.

—. "Grupo de Renovación Musical". Anuario Cultural de Cuba, 1943. La Habana: Dirección de Relaciones Culturales del Ministerio de Estado, 1944.

Ayerza de Castillo, Laura y Odile Felgine. Victoria Ocampo. Barcelona: Circe, 1998.

Beaumont, Cyril W. Michel Fokine \& His Ballets. Londres: Wyman \& Sons, 1945.

Carpentier, Alejo. La música en Cuba. México: Fondo de Cultura Económica, 1980.

Crónicas caribeñas. La Habana: Letras Cubanas, 2012.

Cingria, Charles-Albert. "Perséphone et la critique". Nouvelle Revue Française $\mathrm{n}^{\circ} 43$ (agosto de 1934): 297-301.

Cruz-Malavé, Arnaldo, pról. y notas. "Julián del Casal". Por José Lezama Lima. 1941. Dallas: La Habana elegante, 2013. Web. 29 abril 2013.

Díaz, Clara. José Ardévol. Correspondencia cruzada. La Habana: Letras Cubanas, 2004.

Frank, Waldo. America Hispana. A Portrait and a Prospect. Nueva York; Londres: Charles Scribner's Sons, 1931.

González, Hilario y Chinolope. Vicisitudes de la luz. La Habana: Letras Cubanas, 2009.

González, Reynaldo. Lezama Lima: el ingenuo culpable. La Habana: Letras Cubanas, 1988.

Gramatges, Harold. 'Sobre 'Nueve piezas' de José Ardévol, y lo cubano en la música de este compositor". La Música (La Habana), II (5): 1-3; enero-marzo de 1949. Web. 29 abril 2013.

Hall, John Richard. Development of the Percussion Ensemble through the Contributions of the Latin American Composers Amadeo Roldan, José Ardévol, Carlos Chávez and Alberto Ginastera. Tesis doctoral The Ohio State Universit, 2003. Web. 29 de abril 2013. 
Lezama Lima, José. “Otra página para Arístides Fernández” [originalmente, "Tiempo negado", 1935]. Tratados en La Habana. Obras completas. La Habana: Letras Cubanas, 2009.

—. "Soledades habitadas por Cernuda". 1936. Imagen y posibilidad. Selecc., pról. y notas Ciro Bianchi Ross. La Habana: Letras Cubanas, 1981.

—. "Inicial". 1937. Verbum. Ed. y pról. Gema Areta Marigó. Sevilla: Editorial Renacimiento; Junta de Andalucía; Consejería de Cultura, 2001.

—_. "El secreto de Garcilaso". 1937. Analecta del reloj. Obras completas. La Habana: Letras Cubanas, 2010.

—_ "Gracia eficaz de Juan Ramón y su visita a nuestra poesía”. 1937. Verbum. Ed. y pról. Gema Areta Marigó. Sevilla: Editorial Renacimiento; Junta de Andalucía; Consejería de Cultura, 2001. - Coloquio con Juan Ramón Jiménez: 1938. Analecta del reloj. Obras completas. La Habana: Letras Cubanas, 2010.

—. "Del aprovechamiento poético". 1938. Analecta del reloj. Obras completas. La Habana: Letras Cubanas, 2010.

—. "Razón que sea". 1939. Espuela de plata. Ed. y pról. Gema Areta. Sevilla: Editorial Renacimiento; Junta de Andalucía: Consejería de Cultura, 2002.

—. "Doctrinal de la anémona". 1939. Analecta del reloj. Obras completas. La Habana: Letras Cubanas, 2010.

—_.Julián del Casal". 1941. Analecta del reloj. Obras completas. La Habana: Letras Cubanas, 2010.

—_. "Extasis de la sustancia destruida". 1943. Nadie parecía. Cuaderno de lo bello con Dios. Pról. Gema Areta Marigó. Sevilla: Editorial Renacimiento; Junta de Andalucía; Consejería de Cultura, 2006.

—_. "Las imágenes posibles". 1949. Analecta del reloj. Obras completas. La Habana: Letras Cubanas, 2010.

__. "Sucesiva o las coordenadas habaneras". 1949-1950. Tratados en La Habana. Obras completas. La Habana: Letras Cubanas, 2009.

—. Antología de la poesía cubana III. Madrid: Verbum, 2002. 
Órbita de Lezama Lima. Ensayo preliminar, selecc. y notas Armando Álvarez Bravo. La Habana: Ediciones Unión, 1966.

- Paradiso. Ed. y coord. Cintio Vitier. México: Colección Archivos, 1988.

—_ "Cortázar y el comienzo de la otra novela". La cantidad hechizada. Obras completas. La Habana: Letras Cubanas, 2010.

—. Poesía completa. La Habana: Letras Cubanas, 1985.

Mallarmé, Stéphane. Divagations. Paris: Bibliothèque Charpentier, 1897. Web. 29 abril 2013.

Martí, José. "El poema del Niágara". Obra literaria. Pról., notas y cronología Cintio Vitier. Caracas: Biblioteca Ayacucho, 1989.

Martínez Laínez, Fernando. Palabra cubana. Madrid: Akal Editor, 1975.

Nietzsche, Friedrich. El nacimiento de la tragedia. Introd., trad. y notas Andrés Sánchez Pascual. Madrid: Alianza Editorial, 1996.

Orbón, Julián. "Ante el próximo estreno de 'Forma'”. Alerta. La Habana, 27 de enero de 1943.

Ortega, Julio. “'La expresión americana': una teoría de la cultura”. Eco: revista de la cultura de Occidente 187 (mayo de 1977): 55-63.

—_. "Lezama Lima y la teoría cultural trasatlántica". La ciudad literaria. Brown University. 22 marzo 2011. Web. 29 abril 2013.

Pacheco Varela, Irina. La Sociedad Pro-Arte Musical. Testimonio de su tiempo. Pról. Graziella Pogolotti. La Habana: Centro Cultural Pablo de la TorrienteBrau, 2011.

Quevedo, Antonio. "La Música". Anuario Cultural de Cuba, 1943.

Rodríguez Feo, José. Mi correspondencia con Lezama Lima. La Habana: Ediciones Unión, 1989.

Stravinsky, Igor. "Igor Strawinskynous parle de 'Perséphone"'. Excelsior, París, 29 de abril de 1934, reproducido en White 580-81.

- An Autobiography. Nueva York-Londres: W. W. Norton \& Company, 1998.

- Poética musical. Tr. Eduardo Grau. Barcelona: Acantilado, 2006.

Stravinsky, Igor y Robert Craft. Memories and Commentaries. Nueva York: Faber and Faber Inc., 2002. 
. Stravinsky in Pictures and Documents. Nueva York: Simon and Schuster, 1978.

Walsh, Stephen. Stravinsky. A Creative Spring: Russia and France 18821934. Nueva York: Alfred A. Knopf, 1999.

White, Eric Walter. Stravinsky. The composer and his Works. Berkeley; Los Angeles: University of California Press, 1979.

Vázquez, María Esther. Victoria Ocampo. Buenos Aires: Planeta, 1991.

Vitier, Cintio. Lo cubano en la poesía. La Habana: Instituto del Libro, 1970.

Xirau, Ramón. Poesía iberoamericana contemporánea. Presentación José María Espinasa. México: Consejo Nacional para la Cultura y las Artes, 1995. 